\title{
PENGARUH LINGKUNGAN KERJA DAN PENGEMBANGAN KARIR TERHADAP KOMITMEN ORGANISASI PADA PT. TIGARAKSA SATRIA
}

\author{
Lina $^{1}$ \\ Program Studi Manajemen STMB Multismart \\ Jalan Merbabu Dalam No. 32 aa-bb Kota Medan \\ linacen214@gmail.com \\ Hendy $^{2}$ \\ Program Studi Manajemen STMB Multismart \\ Jalan Merbabu Dalam No. 32 aa-bb Kota Medan \\ huihendy@gmail.com
}

\begin{abstract}
Abstrak
The importance of paying attention to employee organizational commitment because employees are the main resource and important asset in the company. Companies must be able to maintain or even improve the quality of their employees so that their employees can produce good organizational commitment. The purpose of this study was to determine and analyze the work environment and career development effect on organizational commitment partially and simultaneously. The research used is research with quantitative methods. The technique of collecting data in this study was done by distributing questionnaires. The data analysis technique in this study used the classical assumption test, multiple regression, hypothesis testing with SPSS 22 software. The population in this study was 56 employees at PT. Tigaraksa Satria. From the research results obtained tcount $<$ ttable $(6.606>1.68)$, meaning that the work environment has a significant effect on organizational commitment. Likewise with the career development variable obtained tcount $<$ ttable (7.144 $>1.68$ ), meaning that career development has a significant effect on organizational commitment. Based on the results of the F test, it shows that Fcount $>$ Ftable $(41.716>3.26)$ and a value of $0.000<0.05$, this indicates that simultaneously the work environment and career development have a significant effect on organizational commitment.
\end{abstract}

Kata Kunci Work Environment, Career Development, Organizational Commitment

\section{PENDAHULUAN}

Dalam perkembangan jaman pada saat ini, berbagai macam aspek keunggulan dibutuhkan oleh setiap perusahaan dalam rangka mencapai tujuannya. Perusahaan sangat memerlukan adanya suatu potensi dan kekuatan internal yang kokoh dalam rangka menghadapi semua tantangan, hambatan serta perubahan yang ada. Faktor utama yang dibutuhkan dalam rangka mewujudkan harapan tersebut adalah faktor sumber daya.

Penilaian sumber daya manusia dapat dilihat dari hasil kerja yang telah dilakukannya melalui Komitmen Organisasi yang dihasilkannya. Sehingga dapat dikatakan sumber daya manusia yang efektif itu menghasilkan Komitmen Organisasi yang baik. Pentingnya memperhatikan Komitmen Organisasi karyawan sebab karyawan termasuk sumber daya utama dan aset penting dalam perusahaan. Perusahaan harus dapat menjaga atau bahkan meningkatkan kualitas karyawannya sehingga karyawannya dapat membuahkan Komitmen Organisasi yang baik.

Komitmen Organisasi yang tinggi perlu didukung dengan aktivitas karyawan yang melebihi harapan. Faktor yang mempengaruhi Komitmen Organisasi kerja yaitu adanya komitmen 
organisasi yaitu lingkungan kerja. Lingkungan Kerja dapat meningkatkan Komitmen Organisasi karyawan dalam perusahaan, sehingga karyawan dapat menyelesaikan tugas sesuai dengan jabatan dan posisi mereka. Lingkungan kerja yang kondusif dan nyaman merupakan suatu pendorong bagi karyawan agar bekerja lebih giat dan sungguh sungguh dalam mencapai tujuan yang diinginkan.

Selain Lingkungan Kerja, faktor yang mempengaruhi Komitmen Organisasi yaitu Pengembangan Karir. Perlu diketahui bahwa setiap perusahaan akan memiliki Pengembangan Karir yang berbeda. Keanekaragaman pekerjaan yang dirancang di dalam perusahaan, atau sifat individu yang ada akan menggambarkan perbedaan tersebut. Pengembangan Karir penting untuk diciptakan karena merupakan persepsi seseorang tentang apa yang diberikan oleh perusahaan dan dijadikan dasar bagi penentuan tingkah laku anggota selanjutnya.

Pengembangan Karir dapat mempengaruhi karyawan dalam memproduksi barang atau jasa. Oleh karena itu, Pengembangan Karir diperlukan untuk meningkatkan keterampilan atau kemampuan karyawan dalam bekerja dan untuk meningkatkan menyelesaikan pekerjaan yang ditugaskan kepada mereka. Dapat disimpulkan bahwa didalam suatu pengembangan karir akan mempengaruhi perilaku para karyawan dan membentuk kerjasama antar karyawan untuk mencapai tujuan bersama didalam perusahaan.

Berdasarkan latar belakang masalah di atas maka tujuan penelitian ini adalah untuk mengetahui dan menganalisis secara parsial dan simultan pengaruh lingkungan kerja dan pengembangan karir terhadap komitmen organisasi pada PT. Tigaraksa Satria.

\section{LANDASAN TEORI}

Perekonomian Indonesia pada kuartal II-2020 terjadi kontraksi -5,32\%, akan tetapi di sektor industri makanan dan minuman masih menjadi salah satu dari lima investasi teratas di antara semua investasi di Indonesia, sehingga memungkinkan adanya pertumbuhan sebesar $0,22 \%$ pada sektor industri makanan dan minuman. (bps, 2020).Perekonomian Indonesia pada kuartal II-2020 terjadi kontraksi $-5,32 \%$, akan tetapi di sektor industri makanan dan minuman masih menjadi salah satu dari lima investasi teratas di antara semua investasi di Indonesia, sehingga memungkinkan adanya pertumbuhan sebesar $0,22 \%$ pada sektor industri makanan dan minuman. (bps, 2020).Perekonomian Indonesia pada kuartal II-2020 terjadi kontraksi -5,32\%, akan tetapi di sektor industri makanan dan minuman masih menjadi salah satu dari lima investasi teratas di antara semua investasi di Indonesia, sehingga memungkinkan adanya pertumbuhan sebesar 0,22\% pada sektor industri makanan dan minuman. (bps, 2020).

Banyak faktor yang mempengaruhi kinerja karyawan, salah satunya adalah variabel lingkungan kerja berpengaruh signifikan terhadap kinerja karyawan yang diteliti oleh Kurniawan \& Heryanto (2019). Berkaitan dengan Lingkungan kerja, hasil survei yang telah dilakukan peneliti dengan Human Resource Development (HRD) di SL Corp Indonesia bahwa pada tempat produksi yang berada pada akses keluar masuk ke kantor pusat, membuat kurang nyamannya karyawan dalam bekerja. Disisi lain pewarnaan ruangan yang kurang bagus, serta keterbatasan sinyal membuat komunikasi antar karyawan kurang baik disaat pandemi. Menurut Sedarmayanti (2017) dalam Burhannudin, Zainul \& Harlie (2019), lingkungan kerja adalah seluruh peralatan kerja dan bahan yang dipakai, sekitar lingkungan dimana individu bekerja, cara kerja, manajemen kerja secara individu atau sebagai kelompok.

Selain variabel lingkungan kerja dan pengembangan karir, variabel komitmen organisasi juga berpengaruh terhadap kinerja karyawan. Dalam penelitian yang dilakukan oleh Nadapdap (2017), Sutarjo, Dkk (2020) Wdyani \& Devy (2021), Dewi, Dkk (2021) menyatakan bahwa komitmen organisasi berpengaruh signifikan terhadap kinerja karyawan. Sedangkan dalam penelitian yang dilakukan oleh Waterkamp, dkk (2017), menyatakan bahwa komitmen organisasi tidak berpengaruh signifikan terhadap kinerja karyawan. Penelitian lain menyebutkan bahwa variabel komitmen organisasi memediasi hubungan lingkungan kerja terhadap kinerja karyawan yang dilakukan oleh Edward \& Purba (2020). Sedangkan penelitian Widyani \& Devy (2021) menyebutkn bahwa komitmen organisasi dapat memediasi hubungan pengembangan karir terhadap kinerja karyawan. 


\section{METODOLOGI PENELITIAN}

Penelitian ini PT. Tigaraksa Satria Jln. Raya Medan Tamora Komplek Pergudangan Mega Trans Center No 9 Blok H-K Tanjung Morawa Kabupaten Deli Serdang. Populasi didalam penelitian ini adalah karyawan PT. Tiga Raksa Satira yang berjumlah 128 karyawan. Sampel adalah bagian dari jumlah dan karakteristik yang dimiliki oleh populasi tersebut (Sugiyono, 2013). Penentuan jumlah sample yang diambil sebagai responden dengan menggunakan rumus slovin. Berikut adalah perhitungan jumlah sampel dengan menggunakan rumus slovin

$$
\begin{gathered}
n=\frac{N}{N \cdot e^{2}+1} \\
\frac{128}{128 \cdot 0,1^{2}+1} \\
n=58
\end{gathered}
$$

Pengumpulan data dalam instrument ini menggunakan angket (Questioner), adalah teknik pengumpulan data yang dilakukan dengan cara memberi seperangkat pertanyaan atau pertanyaan tertulis dalam bentuk angket kepada responden untuk dijawabnya yang ditujukan kepada para karyawan PT. Tigaraksa Satria dengan menggunakan skala likert dalam bentuk checklist. Teknik analisis yang digunakan dalam penelitian ini adalah analisis data kuantitatif, yakni menguji dan menganalisis data dengan perhitungan angka-angka dan kemudian menarik kesimpulan dari pengujian tersebut dengan alat uji korelasi product moment dan korelasi berganda tetapi dalam praktiknya pengolahan data penelitian ini tidak diolah secara manual,namun menggunakan software statistik SPSS versi 22.

\section{HASIL DAN PEMBAHASAN}

\section{Uji Asumsi Klasik}

\section{Uji Normalitas}

Tujuan dilakukannya uji normalitas tentu saja untuk mengetahui apakah suatu variabel normal atau tidak. Normal disini dalam arti mempunyai distribusi data yang normal. Normal atau tidaknya data berdasarkan patokan distribusi normal data dengan mean dan standar deviasi yang sama.

Untuk mengetahui apakah data penelitian ini memiliki normal atau tidak bisa melihat dari uji normalitas melalui SPSS apakah membentuk data yang normal atau tidak.

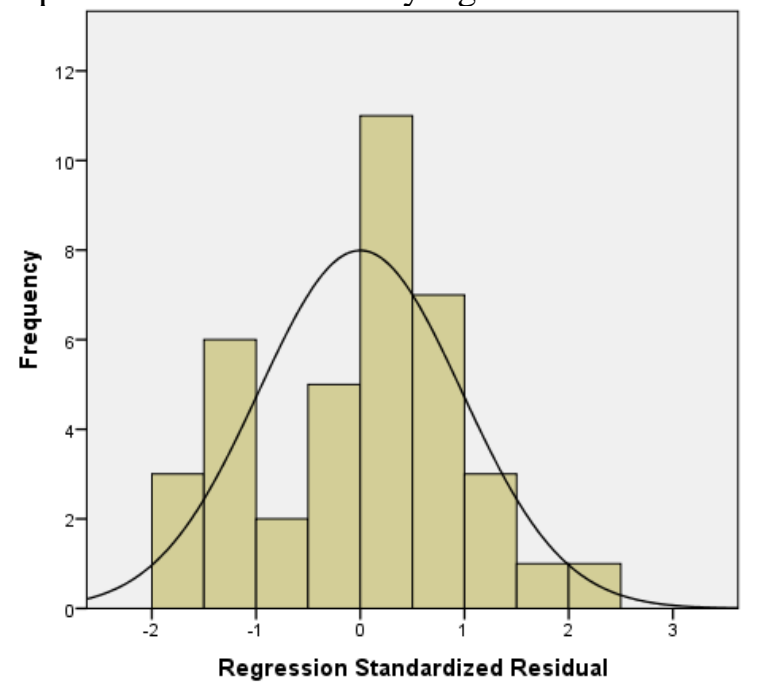

Gambar 1. Histogram 


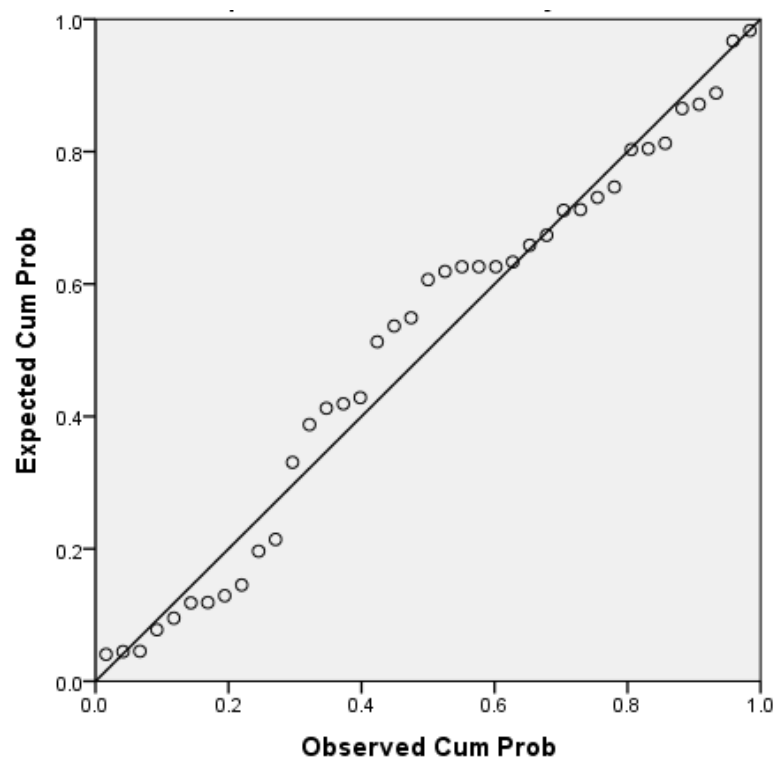

Gambar 2. P-Plot

Dari gambar tersebut di dapatkan hasil bahwa semua data berdistribusi secara normal, sebaran data berada di sekitar garis diagonal.

\section{Uji Multikolinearitas}

Uji multikolinearitas bertujuan untuk menguji apakah model regresi ditemukan adanya korelasi antar variabel bebas (independen)". Pada model regresi yang baik seharusnya tidak terjadi korelasi antar variabel independen, karena korelasi yang tinggi antara variabel-variabel bebas dalam suatu model regresi linear berganda (Ghozali. I, 2005). Jika ada korelasi yang tinggi di antara variabel-variabel bebasnya, maka hubungan antara variabel bebas terhadap variabel terikatnya menjadi terganggu Pengujian multikolinearitas dilakukan dengan melihat VIF antar variabel independen. Jika VIF menunjukkan angka lebih kecil dari 10 menandakan tidak terdapat gejala multikolinearitas. Disamping itu, suatu model dikatakan terdapat gejala multikolinearitas jika nilai VIF diantara variabel independen lebih besar dari 10.

\section{Tabel 1. Uji Multikolinearitas}

\begin{tabular}{|rl|r|c|}
\hline \multirow{2}{*}{ Model } & \multicolumn{2}{|c|}{ Collinearity Statistics } \\
\cline { 3 - 4 } & Tolerance & \multicolumn{1}{c|}{ VIF } \\
\hline 1 & $\begin{array}{l}\text { (Constant) } \\
\text { Lingkungan } \\
\text { kerja } \\
\text { Pengembangan } \\
\text { karir }\end{array}$ & .546 & 1.831 \\
\hline
\end{tabular}

Sumber : Hasil Perhitungan SPSS 22 (data diolah), Tahun 2021

Dari data diatas setalah diolah menggunakan SPSS dapat diliha bahwa nilai tolerance setiap variabel lebih kecil nilai VIF < 10 hal ini membuktikan bahwa nilai VIF setiap variabelnya bebas dari gejala multikolinearitas.

\section{Uji Heterokedastisitas}

Uji heteroskedastisitas bertujuan menguji apakah dalam model regresi terjadi ketidaksamaan variance dari residual satu pengamatan ke pengamatan yang lain, karena karena untuk melihat apakah terdapat ketidaksamaan varians dari residual satu ke pengamatan ke pengamatan yang lain (Ghozali. I, 2005). Model regresi yang memenuhi persyaratan adalah di mana terdapat kesamaan varians dari residual satu pengamatan ke pengamatan yang lain tetap atau disebut 
homoskedastisitas. Suatu model regresi yang baik adalah tidak terjadi heteroskedastisitas. Ada beberapa cara untuk menguji ada tidaknya situasi heteroskedastisitas dalam varian error terms untuk model regresi. Dalam penelitian ini akan digunakan metode chart (Diagram Scatterplot), dengan dasar pemikiran bahwa :

1) Jika ada pola tertentu seperti titik-titik (poin-poin), yang ada membentuk suatu pola tertentu yang beraturan (bergelombang, melebar, kemudian menyempit), maka terjadi heteroskedastisitas.

2) Jika ada pola yang jelas, serta titik-titik menyebar keatas dan dibawah 0 pada sumbu Y maka tidak terjadi heteroskedastisitas.

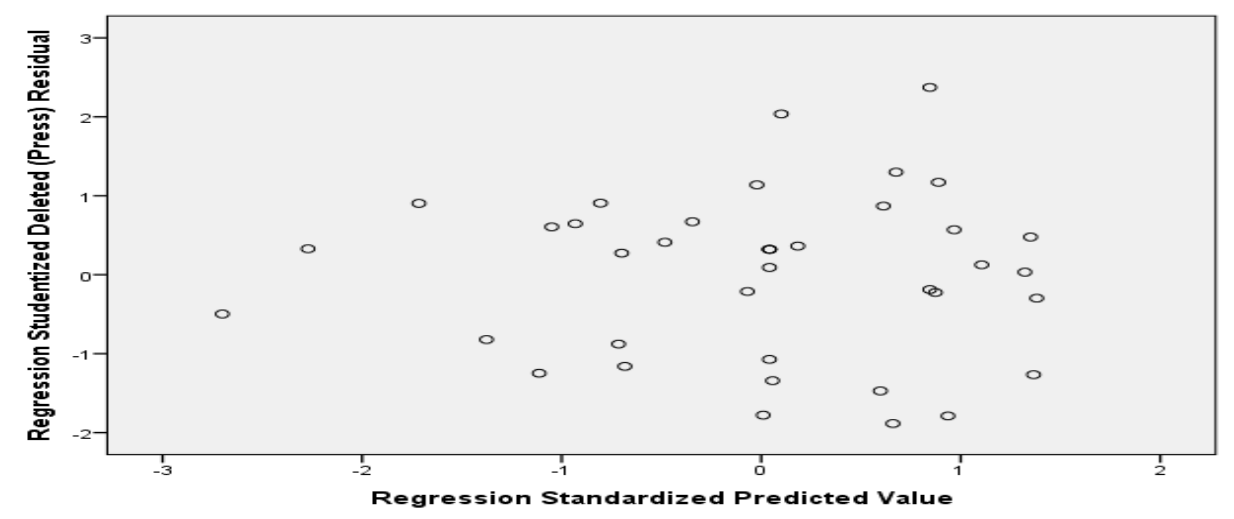

Gambar 3. Scaterplot

\section{Uji Hipotesis}

\section{Regresi Linier Berganda}

Analisis data dalam penelitian ini menggunakan analisis regresi berganda. Dalam penelitian ini terdapat dua variabel independen, yaitu lingkungan kerja dan pengembangan karir serta satu variabel dependen yaitu Komitmen organisasi. Adapun rumus dari regresi linier berganda adalah sebagai berikut :

$\mathrm{Y}=\mathrm{a}+\mathrm{b}_{1} \mathrm{X} 1+\mathrm{b}_{2} \mathrm{X} 2+\mathrm{e}$

Tabel 2. Regresi Berganda

\begin{tabular}{|c|c|c|c|c|c|c|}
\hline \multirow{2}{*}{\multicolumn{2}{|c|}{ Model }} & \multicolumn{2}{|c|}{ Unstandardized Coefficients } & \multirow{2}{*}{$\begin{array}{c}\begin{array}{c}\text { Standardized } \\
\text { Coefficients }\end{array} \\
\text { Beta }\end{array}$} & \multirow[b]{2}{*}{$\mathrm{t}$} & \multirow[b]{2}{*}{ Sig. } \\
\hline & & $\mathrm{B}$ & Std. Error & & & \\
\hline 1 & (Constant) & 11.335 & 4.927 & & 2.301 & .027 \\
\hline & $\begin{array}{l}\text { Lingkungan } \\
\text { kerja }\end{array}$ & .102 & .168 & .751 & 6.606 & .000 \\
\hline & $\begin{array}{l}\text { Pengembangan } \\
\text { karir }\end{array}$ & .195 & .167 & .885 & 7.144 & .000 \\
\hline
\end{tabular}

Sumber : Hasil Perhitungan SPSS 22 (data diolah), Tahun 2021

1. Pada model regresi ini, nilai konstanta yang tercantum sebesar 11,335 dapat diartikan jika variabel bebas dalam model diasumsikan sama dengan nol, secara rata-rata variabel diluar model tetap akan meningkatkan Komitmen organisasi sebesar 11,335 satu-satuan atau dengan kata lain jika variabel lingkungan kerja dan pengembangan karir tidak ditingkatkan, maka Komitmen organisasi masih sebesar 11,335.

2. Nilai koefisien regresi b1 sebesar 0,102 pada penelitian ini dapat diartikan bahwa variabel Lingkungan kerja (X1) memiliki hubungan yang positif terhadap Komitmen organisasi pada ASN di PT. Tigaraksa Satria. Hal ini menunjukkan bahwa ketika Lingkungan kerja mengalami peningkatan sebesar satu satuan, maka akan meningkatkan Komitmen organisasi sebesar 0,102.

3. Nilai koefisien regresi b2 sebesar 0,102 pada penelitian ini dapat diartikan bahwa variabel pengembangan karir (X2) memiliki hubungan yang positif terhadap Komitmen organisasi pada 
ASN di PT. Tigaraksa Satria. Hal ini menunjukkan bahwa ketika pengembangan karir mengalami peningkatan sebesar satu satuan, maka akan meningkatkan Komitmen organisasi sebesar 0,102

\section{b. Uji t}

Tabel 3. Uji t

\begin{tabular}{|c|c|c|c|c|c|c|}
\hline \multirow{2}{*}{\multicolumn{2}{|c|}{ Model }} & \multicolumn{2}{|c|}{ Unstandardized Coefficients } & \multirow{2}{*}{$\begin{array}{c}\begin{array}{c}\text { Standardized } \\
\text { Coefficients }\end{array} \\
\text { Beta }\end{array}$} & \multirow[b]{2}{*}{$\mathrm{t}$} & \multirow[b]{2}{*}{ Sig. } \\
\hline & & $\mathrm{B}$ & Std. Error & & & \\
\hline \multirow[t]{3}{*}{1} & (Constant) & 11.335 & 4.927 & & 2.301 & .027 \\
\hline & $\begin{array}{l}\text { Lingkungan } \\
\text { kerja }\end{array}$ & .102 & .168 & .751 & 6.606 & .000 \\
\hline & $\begin{array}{l}\text { Pengembangan } \\
\text { karir }\end{array}$ & .195 & .167 & .885 & 7.144 & .000 \\
\hline
\end{tabular}

Sumber : Hasil Perhitungan SPSS 22 (data diolah), Tahun 2021

Dari tabel regresi dapat dilihat besarnya thitung untuk variabel lingkungan kerja sebesar 6.606 dengan nilai signifikan 0,000, sedangkan $t_{\text {tabel }}$ adalah 1,68, sehingga $t_{h i t u n g}<t_{\text {tabel }}(6.606>1,68)$, maka lingkungan kerja menunjukkan angka $<0,05(0,000<0,05)$, maka Ha diterima dan H0 ditolak, artinya lingkungan kerja berpengaruh signifikan terhadap komitmen organisasi.

Dari tabel regresi dapat dilihat besarnya thitung untuk variabel pengembangan karir sebesar 7,144 dengan nilai signifikan 0,000, sedangkan $t_{\text {tabel }}$ adalah 1,68, sehingga $t_{h i t u n g}<t_{\text {tabel }}(7.144>1,68)$, maka lingkungan kerja menunjukkan angka $<0,05(0,000<0,05)$, maka Ha diterima dan $\mathrm{H} 0$ ditolak, artinya pengembangan karir berpengaruh signifikan terhadap komitmen organisasi karyawan.

\section{c. Uji F}

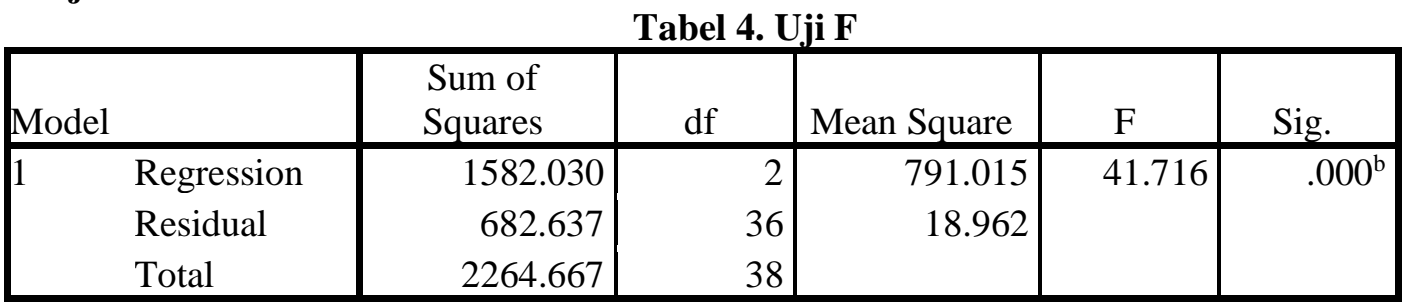

Sumber : Hasil Perhitungan SPSS 22 (data diolah), Tahun 2021

Berdasarkan hasil uji $\mathrm{F}$ diatas maka dapat dilihat bahwa $\mathrm{F}_{\text {hitung }}>\mathrm{F}_{\text {tabel }}(41.716>3.26)$ dan nilai $0.000<0.05$ hal ini menunjukkan bahwa secara simultan lingkungan kerja dan pengembangan karir kerja berpengaruh signifikan terhadap komitmen organisasi

\section{d. Koefisien Determinasi}

Koefisien determinasi $\left(\mathrm{R}^{2}\right)$ digunakan untuk melihat kemampuan model dalam menjelaskan variabel independen terhadap variabel dependen dari model yang dibangun. Berdasarkan hasil pengujian statistik untuk model dengan variabel independen.

Tabel 5. Nilai Koefisien Determinasi

\begin{tabular}{|l|r|r|r|}
\hline Model & \multicolumn{1}{|c|}{$\mathrm{R}$} & R Square & \multicolumn{1}{c|}{$\begin{array}{c}\text { Adjusted } \mathrm{R} \\
\text { Square }\end{array}$} \\
\hline 1 & $.836^{\mathrm{a}}$ & .699 & .682 \\
\hline
\end{tabular}

Sumber : Hasil Perhitungan SPSS 22 (data diolah), Tahun 2021

Koefisien determinasi dengan nilai Adjusted $R$ Square sebesar 0,836 berarti variabel independen mampu menjelaskan variasi variabel dependen hanya sebesar $83.6 \%$, sisanya sebesar $16.4 \%$ diterangkan oleh variabel lain di luar model yang terangkum dalam error 


\section{Pembahasan Hasil Penelitian}

\section{Pengaruh Lingkungan kerja Terhadap Komitmen organisasi}

Dari tabel regresi dapat dilihat lingkungan kerja berpengaruh signifikan terhadap komitmen organisasi pada PT. Tigaraksa Satria. Hal ini menunjukkan bahwa lingkungan kerja dipengaruh oleh besarnya lingkungan kerja yang diterima oleh karyawan. Lingkungan kerja merupakan suatu fungsi Manajemen yang perlu dilaksanakan terus-menerus dalam rangka pembinaan ketenagaan dalam organisasi. Secara spesifik, proses perbaikan lingkungan kerja merupakan tindakan (upaya), yang dilaksanakan secara berkesinambungan, bertahap dan terpadu. Tiap proses perbaikan lingkungan kerja harus terarah untuk mencapai tujuan tertentu terkait dengan upaya pencapaian tujuan organisasi.

Lingkungan kerja kerja sangat penting bagi tenaga kerja untuk bekerja lebih menguasai dan lebih terhadap pekerjaan yang dijabat atau akan dijabat kedepan. Tidak terlalu jauh dalam lingkungan kerja sering dilakukan sebagai upaya meningkatkan komitmen organisasi para pegawai yang dianggap belum mampu untuk mengemban pekerjaannya karena faktor perkembangan kebutuhan masyarakat.

Lingkungan kerja merupakan aktivitas operasional yang sangat penting dalam perusahaan. Kualitas dari karyawan dapat dikembangkan di dalam lingkungan kerja itu sendiri. Untuk menghasilkan karyawan yang memiliki pengetahuan keahlian dan sikap mental yang sesuai dengan yang dibutuhkan perusahaan maka penyelenggaraan lingkungan kerja merupakan suatu keharusan. Melalui adanya lingkungan kerja akan meningkatkan komitmen organisasi karyawan sehingga dapat menunjang keberhasilan perusahaan.

\section{Pengaruh Pengembangan karir Kerja Terhadap Komitmen organisasi}

Dari tabel regresi dapat dilihat besarnya $t_{\text {hitung }}$ untuk variabel pengembangan karir sebesar 7,144 dengan nilai signifikan 0,000, sedangkan $t_{\text {tabel }}$ adalah 1,68, sehingga $t_{h i t u n g}<t_{\text {tabel }}(7.144>1,68)$, maka lingkungan kerja menunjukkan angka $<0,05(0,000<0,05)$, maka Ha diterima dan H0 ditolak, artinya pengembangan karir berpengaruh signifikan terhadap komitmen organisasi.

Pengembangan karir kerja sangat penting dalam menjalankan usaha suatu organisasi. Dengan memperoleh pengembangan karir kerja, maka tugas yang dibebankan dapat dikerjakan dengan baik. Sedangkan pengembangan karir kerja jelas sangat mempengaruhi komitmen organisasi karyawan karena dengan mempunyai pengembangan karir kerja, maka komitmen organisasipun akan meningkat. Pengembangan karir kerja bekerja yang dimiliki seseorang, kadang -kadang lebih dihargai daripada tingkat pendidikan yang menjulang tinggi.

Karyawan mempunyai pengembangan karir kerja tinggi maka dapat meningkatkan komitmen organisasi karyawan. Artinya semakin banyak pengembangan karir kerja seorang karyawan maka komitmen organisasi karyawan akan semakin tinggi pula. Sebaliknya semakin sedikit pengembangan karir kerja karyawan maka komitmen organisasi karyawan juga semakin rendah. Indikator dari pengembangan karir kerja adalah Lama waktu/masa kerja, Tingkat pengetahuan, Pendidikan, Penataran

Lama waktu/masa kerja Ukuran tentang lama waktu atau masa kerja yang telah di tempuh seseorang dapat memahami tugas-tugas suatu pekerjaan dan telah melaksanakan dengan baik. Berdasarkan pendidikan yang dilaksanakan oleh seseorang, maka orang tersebut dapat memperoleh pengembangan karir kerja yang lebih banyak dari sebelumnya. Melalui kegiatan penataran dan sejenisnya, maka sesorang akan memperoleh pengembangan karir kerja untuk diterapkan sesuai dengan kemampuannya. Pengetahuan merujuk pada konsep, prinsip, prosedur, kebijakan atau informasi lain yang dibutuhkan oleh karyawan. Pengetahuan juga mencakup kemampuan untuk memahami dan menerapkan informasi pada tanggung jawab pekerjaan.

\section{KESIMPULAN}

Dari hasil analisis yang telah di bahas sebelumnya, maka dapat di ambil kesimpulan sebagai berikut : Berdasarkan hasil penelitian diperoleh $t_{\text {hitung }}<t_{t a b e l}(6.606>1,68)$, maka lingkungan kerja menunjukkan angka $<0,05(0,000<0,05)$, maka Ha diterima dan H0 ditolak, artinya lingkungan kerja berpengaruh signifikan terhadap komitmen organisasi. Berdasarkan hasil 
penelitian diperoleh $t_{\text {hitung }}<\mathrm{t}_{\text {tabel }}(7.144>1,68)$, maka lingkungan kerja menunjukkan angka $<$ $0,05(0,000<0,05)$, maka Ha diterima dan $\mathrm{H} 0$ ditolak, artinya pengembangan karir berpengaruh signifikan terhadap komitmen organisasi karyawan. Berdasarkan hasil uji $\mathrm{F}$ diatas maka dapat dilihat bahwa $F_{\text {hitung }}>F_{\text {tabel }}(41.716>3.26)$ dan nilai $0.000<0.05$ hal ini menunjukkan bahwa secara simultan lingkungan kerja dan pengembangan karir kerja berpengaruh signifikan terhadap komitmen organisasi

\section{DAFTAR PUSTAKA}

Ardana, I. K., Mujiati, N. W., \& Utama, I. W. M. (2012). Manajemen Sumber Daya Manusia. Yogyakarta: Graha Ilmu.

Ghozali. I. (2005). Analisis Multivariat Dengan Menggunakan SPSS. Semarang: Undip.

Idrus, M. (2006). Implikasi Iklim Organisasi Terhadap Kepuasan Kerja Dan Kualitas Kehidupan Kerja Karyawan. Jurnal Psikologi Universitas Diponegoro, 3(1), 94-106.

Mangkunegara, A. A. P. (2014). Evaluasi Kinerja SDM/SM-17. Bandung: PT Refika Aditama.

Sugiyono. (2010). Metode Penelitian Pendidikan Pendekatan Kuantitatif, kualitatif, dan R\&D. Bandung: Alfabeta.

Sugiyono. (2013a). Metode Penelitian Bisnis (8th ed.). Bandung: Alfabeta.

Sugiyono. (2013b). Metodologi Penelitian Kuantitatif dan Kualitatif. Bandung: Alfabeta. 